\title{
The use of biochemical fingerprinting, phage typing and antimicrobial-susceptibility, testing in the detection of epidemic strains of Salmonella of serotype Typhimurium in Iran
}

\author{
M. KATOULI, R. WOLLIN*, I. KÜHN*, A. A. FARHOUDI-MOGHADDAM† and R. MÖLLBY \\ Department of Bacteriology, Karolinska Institute, S-104 01 Stockholm, * The National Bacteriological Laboratory, \\ S-105 21 Stockholm, Sweden and † Microbiology Department, Pasteur Institute of Iran, Tehran 13164, Iran
}

\begin{abstract}
Summary. A collection of 86 strains of Salmonella of serotype Typhimurium isolated from children with gastroenteritis in Tehran, Iran was examined for biochemical phenotype, phage type and antibiotic-resistance pattern. Twenty-seven biochemical phenotypes (BPTs), 14 discrete phage types (PTs) and 18 resistotypes (RTs) were identified. Fifty-three strains $(62 \%)$ belonged to two major and probably related BPTs, whereas the other 33 isolates belonged to less common BPTs. The two predominant BPTs contained 26 strains of the same PT and 23 strains of the same RT. Different PTs and RTs of strains with similar BPT were sometimes observed, possibly reflecting antibiotic pressures in Iran. These results suggest that two major "clones" of Typhimurium strains are particularly common in Iran and, although each method alone adequately detected these and other less common "clones", biochemical fingerprinting provided additional information about relationships among strains.
\end{abstract}

\section{Introduction}

Strains of Salmonella of serotype Typhimurium are increasingly associated with outbreaks of food-borne disease worldwide. ${ }^{1-3}$ In Iran, Typhimurium was the major salmonella serotype isolated in a 3-year period. ${ }^{4}$ When typing antisera are available, identification of strains as Typhimurium rarely causes problems in routine clinical laboratories. However, in order to obtain a better understanding of its epidemiology, additional typing of Typhimurium strains will usually be required. The success of this goal depends on methods that discriminate and distinguish strains from different sources. Various techniques reported for typing Typhimurium strains include biotyping, ${ }^{5}$ phage typing, ${ }^{6.7}$ antimicrobial-sensitivity testing, ${ }^{7}$ plasmid analysis, ${ }^{9,10}$ multilocus-enzyme electrophoresis ${ }^{11}$ and restriction-endonuclease analysis of chromosomal DNA. ${ }^{12,13}$ Because genetic variation in the typing characters of epidemic strains in the course of their epidemic spread may be expected, multiple typing is thought to provide a better picture of the "clonal" relationship among isolates. ${ }^{14}$

An automated typing method, based on biochemical fingerprinting (the $\mathrm{PhP}$-system) reported elsewhere, ${ }^{15,16}$ gives a quantitative value of the metabolism of various substrates by measuring the speed and intensity of each reaction. The "biochemical fingerprint" of each isolate is used to calculate with a personal computer similarities among strains tested with results shown in the form of a dendrogram. In another study, ${ }^{17}$ with a set of substrates specially chosen to subdivide Typhimurium strains, the system was shown to be highly discriminatory. In this study the $\mathrm{PhP}$-system was used along with phage typing and antimicrobial testing to investigate relationships among epidemic strains of Typhimurium isolated from children with gastroenteritis in Iran.

\section{Materials and methods}

\section{Bacterial strains}

The 86 Typhimurium strains studied had been isolated from children $<5$ years old with severe diarrhoea who attended children's hospitals in Tehran, Iran, between Feb. 1985 and March 1986. Identification of strains and determination of antibioticresistance patterns have been described before. ${ }^{4}$ Strains were kept on nutrient-agar slopes at $4^{\circ} \mathrm{C}$ until tested for lysogenic pattern and biochemical phenotype.

\section{Antibiotic resistance}

Strains were tested against the antibiotics most commonly used in Iran, including chloramphenicol 
Table I. Phage types, biochemical phenotypes and resistotypes of 86 Typhimurium strains isolated in Iran

\begin{tabular}{|c|c|c|c|c|c|}
\hline $\begin{array}{l}\text { Phage } \\
\text { type }\end{array}$ & $\begin{array}{l}\text { Number of } \\
\text { strains }\end{array}$ & $\begin{array}{l}\text { Biochemical } \\
\text { phenotype }\end{array}$ & $\begin{array}{c}\text { Number of } \\
\text { strains }\end{array}$ & Resistotype & $\begin{array}{c}\text { Number of } \\
\text { strains }\end{array}$ \\
\hline $\begin{array}{l}\text { 2NST } \\
3 \mathrm{NST} \\
4 \\
5 \mathrm{NST} \\
7 \mathrm{NSTa} \\
7 \mathrm{NSTb} \\
8 \\
8 \mathrm{NSTa} \\
8 \mathrm{NSTb} \\
11 \mathrm{NSTa} \\
11 \mathrm{NSTb} \\
18 \\
21 \\
22 \\
\text { NT }\end{array}$ & $\begin{array}{r}1 \\
1 \\
4 \\
7 \\
1 \\
3 \\
1 \\
1 \\
2 \\
8 \\
2 \\
1 \\
31 \\
9 \\
14\end{array}$ & $\begin{array}{l}\text { A1 } \\
\text { A2 } \\
\text { A3 } \\
\text { A4 } \\
\text { A5 } \\
\text { A6 } \\
\text { B1 } \\
\text { B2 } \\
\text { B3 } \\
\text { B4 } \\
\text { B5 } \\
\text { B6 } \\
\text { B7 } \\
\text { B8 } \\
\text { B9 } \\
\text { B10 } \\
\text { B11 } \\
\text { B12 } \\
\text { C1 } \\
\text { C2 } \\
\text { C3 } \\
\text { C4 } \\
\text { C5 } \\
\text { D1 } \\
\text { E1 } \\
\text { F1 } \\
\text { G1 }\end{array}$ & $\begin{array}{r}3 \\
2 \\
2 \\
1 \\
2 \\
1 \\
43 \\
1 \\
1 \\
10 \\
1 \\
1 \\
2 \\
1 \\
2 \\
1 \\
1 \\
1 \\
1 \\
1 \\
2 \\
1 \\
1 \\
1 \\
1 \\
1 \\
1\end{array}$ & $\begin{array}{r}388 \\
387 \\
386 \\
385 \\
380 \\
375 \\
373 \\
368 \\
365 \\
330 \\
285 \\
280 \\
275 \\
185 \\
158 \\
135 \\
115 \\
0\end{array}$ & $\begin{array}{r}1 \\
4 \\
1 \\
33 \\
15 \\
2 \\
1 \\
1 \\
2 \\
3 \\
9 \\
1 \\
1 \\
3 \\
1 \\
2 \\
1 \\
5\end{array}$ \\
\hline
\end{tabular}

(C), cotrimoxazole (SxT), ampicillin (A), tetracycline (T), kanamycin $(\mathrm{K})$, nalidixic acid $(\mathrm{Nx})$, streptomycin (S), cephalothin (Cf), and furoxone (F). Resistance to antibiotics was coded as follows: $C=200, T=100$, $\mathrm{A}=50, \mathrm{SxT}=20, \mathrm{~K}=10, \mathrm{~S}=5, \mathrm{Cf}=2$ and $\mathrm{Nx}=1$ with sensitivity to each antibiotic coded as 0 . The sum of the values of the antibiotics to which strains were resistant was used to indicate the antibiotic resistotype (RT). Thus, an RT of 385 indicated a strain that was resistant to C, T, A, SxT, K, S whereas an RT of 0 indicated a strain that was sensitive to all antibiotics tested.

\section{Phage typing}

Strains were phage typed by the scheme of Lilleengen, ${ }^{18}$ exactly as described elsewhere ${ }^{17}$. As well as recognised phage-type patterns, some strains gave lytic patterns that were of non-specific types (NSTs) and other strains were not phage-typable (NT).

\section{Biochemical fingerprinting}

The principle of the $\mathrm{PhP}$-system and the preparation of the plates have been described previously. ${ }^{15,16}$ Each isolate was subjected to 16 biochemical tests specially chosen to subdivide Typhimurium strains. ${ }^{17}$ The absorbance, $A_{620}$, of each reaction was measured after 4 , 7,24 and $48 \mathrm{~h}$ and the mean value of four readings was calculated. Similarities among strains were calculated as correlation coefficients $(\mathbf{r})^{15-17}$ and clustered according to the unweighted-pair group method with arithmetic averages (UPGMA) ${ }^{19}$ to yield a dendrogram. Strains with $\mathbf{r}$ values greater than the identity level (0.980) used in the PhP-system were assigned to the same biochemical phenotype (BPT). BPTs with $>1$ isolate were called common BPTs and those with only one isolate were called single BPTs.

\section{Results}

The results obtained when isolates of Typhimurium were typed by each of the methods are summarised in table I. Eighty-one strains were resistant to between three and eight antibiotics and the most common RTs were 385 ( 33 isolates), 380 (15 isolates) and 285 (nine isolates); the latter RTs differed from RT 385 in sensitivity to $S$ and $T$, respectively. Strains of these three RTs accounted for $66 \%$ of the population tested. Only five isolates were fully sensitive to the antibiotics tested. In all, 18 different RTs were identified.

Seventy-two isolates were assigned to 14 discrete PTs and 14 were not typable (NT) (table I). The most common PTs were 21 (31 isolates), 22 (nine isolates), 11 NSTa (eight isolates) and 5NST (seven isolates) which together accounted for $c .64 \%$ of the strains.

Biochemical fingerprinting distinguished 27 BPTs with nine common and 18 single phenotypes. At the similarity level of 0.80 , isolates grouped into seven 


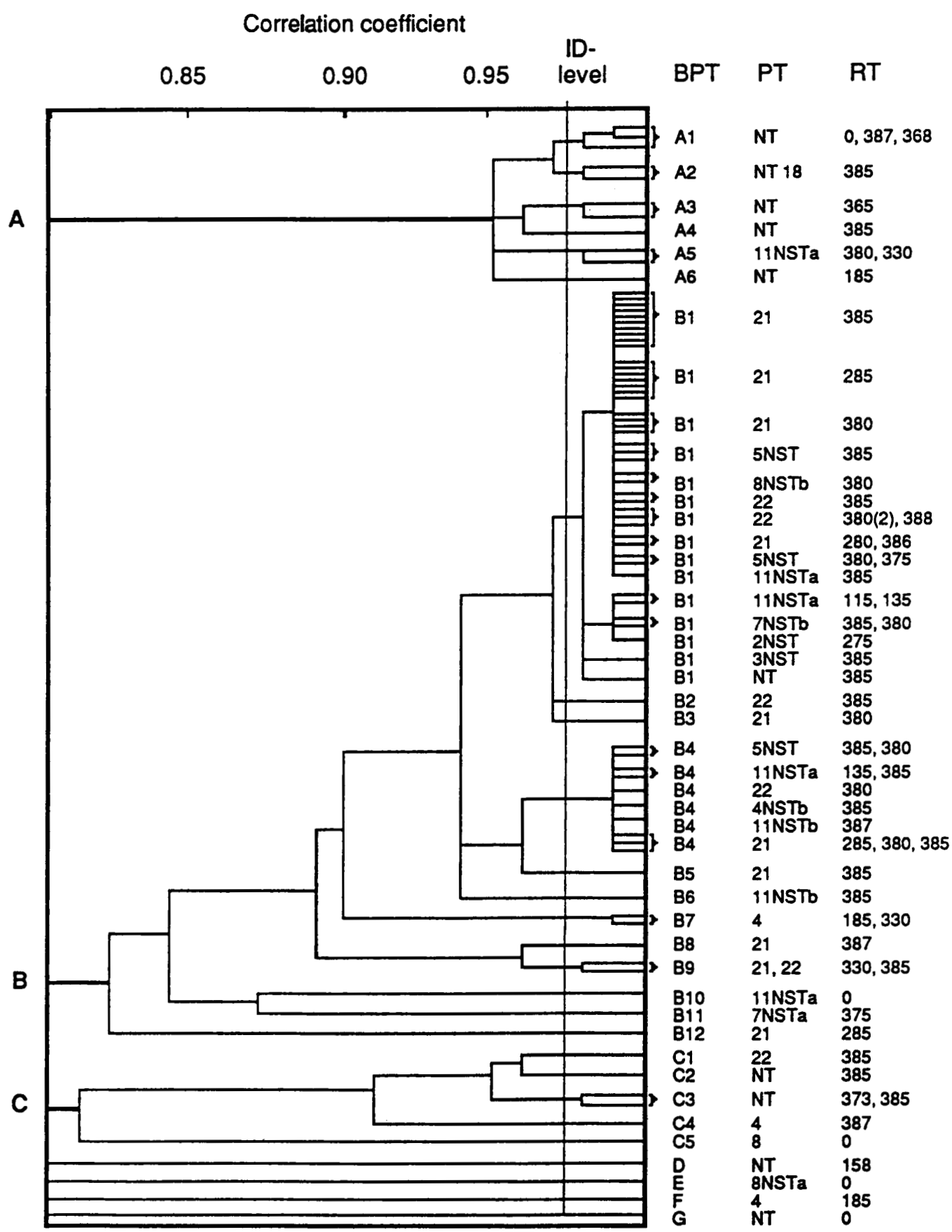

Figure. Grouping ("clones”) of 86 Typhimurium strains by biochemical phenotype (BPT), phage type (PT) and antimicrobial-susceptibility pattern (RT).

clusters (figure). Strains in cluster A were characterised by their inability to ferment galactonic-lactone (galn -). Cluster B, which consisted of galn + strains, accounted for $76 \%$ of the isolates, with B1 (43 isolates) and B4 (10 isolates) dominating this cluster (figure); strains of B1 and B4 differed in their rate of trehalose fermentation. Cluster C, like cluster B, contained galn + strains which, however, fermented tagatose slowly. Strains of BPTs D, E and F did not ferment inositol (ino-) or rhamnose (rha-) and strains of BPT F also failed to ferment galactonic-lactone. BPT $G$ differed from the other strains in many biochemical reactions, including inositol and rhamnose (figure).

Biochemical fingerprinting together with phage typ- ing yielded 41 "clonal" groupings (having the same BPT and PT) consisting of 14 common and 28 single phenotypes (table II). The dominant phenotype was B1/21 (23 strains); the closely related BPT B4 contained three strains of PT 21. A similar pattern was obtained when biochemical fingerprinting and resistotyping were used together (table III), with 46 BPT/RT groups (having the same BPT and RT) consisting of seven common and 39 single phenotype identified. The predominant BPT/RTs were B1/385 (19 strains), B1/380 (10 strains) and B1/285 (seven strains), strains of the latter differing from those of B1/385 only in resistance to $S$ and $T$, respectively. Four strains of phenotype B4 also belonged to RT 385 (table III). The use of the three typing methods 
Table II. Grouping of 86 Typhimurium strains isolated in Iran by biochemical phenotype and phage type

\begin{tabular}{|c|c|c|c|c|}
\hline \multicolumn{2}{|c|}{ Common types } & \multirow{2}{*}{$\begin{array}{c}\text { Number of } \\
\text { isolates }\end{array}$} & \multicolumn{2}{|c|}{ Single types } \\
\hline $\begin{array}{l}\text { Biochemical } \\
\text { phenotype }\end{array}$ & $\begin{array}{l}\text { Phage } \\
\text { type }\end{array}$ & & $\begin{array}{l}\text { Biochemical } \\
\text { phenotype }\end{array}$ & $\begin{array}{l}\text { Phage } \\
\text { type }\end{array}$ \\
\hline \multirow[t]{2}{*}{ Al } & NT & 3 & & \\
\hline & & & A2 & $\begin{array}{l}\text { NT } \\
18\end{array}$ \\
\hline A3 & NT & 2 & & \\
\hline \multirow[t]{2}{*}{ A5 } & 11NSTa & 2 & A4 & NT \\
\hline & & & A6 & NT \\
\hline \multirow[t]{3}{*}{ B1 } & $\begin{array}{l}21 \\
22 \\
11 \mathrm{NSTa} \\
\text { 8NSTb } \\
\text { 7NSTb } \\
\text { 5NST }\end{array}$ & $\begin{array}{r}23 \\
5 \\
3 \\
2 \\
2 \\
5\end{array}$ & & \\
\hline & & & B1 & $\begin{array}{l}\text { 3NST } \\
\text { 2NST } \\
\text { NT }\end{array}$ \\
\hline & & & $\begin{array}{l}\text { B2 } \\
\text { B3 }\end{array}$ & $\begin{array}{l}22 \\
21\end{array}$ \\
\hline \multirow[t]{3}{*}{ B4 } & $\begin{array}{l}21 \\
1 \mathrm{INSTa} \\
5 \mathrm{NST}\end{array}$ & $\begin{array}{l}3 \\
2 \\
2\end{array}$ & & \\
\hline & & & B4 & $\begin{array}{l}7 \mathrm{NST} b \\
22 \\
11 \mathrm{NST} \text { b }\end{array}$ \\
\hline & & & $\begin{array}{l}\text { B5 } \\
\text { B6 }\end{array}$ & $\begin{array}{l}21 \\
11 \mathrm{NST} b\end{array}$ \\
\hline \multirow[t]{2}{*}{ B7 } & 4 & 2 & & \\
\hline & & & $\begin{array}{l}\text { B8 } \\
\text { B9 } \\
\text { B9 } \\
\text { B10 } \\
\text { B11 } \\
\text { B12 } \\
\text { C1 } \\
\text { C2 }\end{array}$ & $\begin{array}{l}21 \\
21 \\
22 \\
11 \mathrm{NSTa} \\
7 \mathrm{NSTa} \\
21 \\
22 \\
\text { NT }\end{array}$ \\
\hline \multirow[t]{2}{*}{$\mathrm{C} 3$} & NT & 2 & & \\
\hline & & & $\begin{array}{l}\text { C4 } \\
\text { C5 } \\
\text { D1 } \\
\text { E1 } \\
\text { F1 } \\
\text { G1 }\end{array}$ & $\begin{array}{c}4 \\
8 \\
\text { NT } \\
8 \mathrm{NSTa} \\
4 \\
\text { NT }\end{array}$ \\
\hline
\end{tabular}

together (figure) revealed eight common and 52 single "clonal" groupings with the BPT/PT/RT B1/21/385 being the most common (10 strains).

\section{Discussion}

These results suggest that there were two major, and probably related, "clones" of serotype Typhimurium causing gastroenteritis in Iran. Although each method alone adequately identified the presence of these and less common "clones", biochemical fingerprinting provided additional information about relationships among strains.

Resistotyping has been considered to be a relatively poor method for strain discrimination, mainly because antibiotic resistance in gram-negative bacteria is generally plasmid-encoded and, hence, strongly influenced by antibiotic pressure in the organisms' environment.
Table III. Grouping of 86 Typhimurium strains isolated in Iran by biochemical phenotype and resistotype

\begin{tabular}{|c|c|c|c|c|}
\hline \multicolumn{2}{|c|}{ Common types } & \multirow{2}{*}{$\begin{array}{c}\text { Number of } \\
\text { strains }\end{array}$} & \multicolumn{2}{|c|}{ Single types } \\
\hline $\begin{array}{l}\text { Biochemical } \\
\text { phenotype }\end{array}$ & $\begin{array}{l}\text { Resisto- } \\
\text { type }\end{array}$ & & $\begin{array}{l}\text { Biochemical } \\
\text { phenotype }\end{array}$ & $\begin{array}{l}\text { Resisto- } \\
\text { type }\end{array}$ \\
\hline & & & Al & $\begin{array}{r}0 \\
388 \\
368\end{array}$ \\
\hline $\begin{array}{l}\text { A2 } \\
\text { A3 }\end{array}$ & $\begin{array}{l}385 \\
365\end{array}$ & $\begin{array}{l}2 \\
2\end{array}$ & & \\
\hline & & & $\begin{array}{l}\text { A4 } \\
\text { A5 }\end{array}$ & $\begin{array}{l}385 \\
380 \\
330 \\
185\end{array}$ \\
\hline B1 & $\begin{array}{l}385 \\
380 \\
285\end{array}$ & $\begin{array}{r}19 \\
10 \\
7\end{array}$ & A6 & 185 \\
\hline & . & & $\begin{array}{l}\text { B2 } \\
\text { B3 }\end{array}$ & $\begin{array}{l}280 \\
386 \\
115 \\
275 \\
375 \\
389 \\
135 \\
385 \\
380\end{array}$ \\
\hline B4 & $\begin{array}{l}385 \\
380\end{array}$ & $\begin{array}{l}4 \\
3\end{array}$ & & \\
\hline & & & B4 & $\begin{array}{l}135 \\
388 \\
285\end{array}$ \\
\hline & & & $\begin{array}{l}\text { B5 } \\
\text { B6 } \\
\text { B7 }\end{array}$ & $\begin{array}{l}385 \\
385 \\
330 \\
185\end{array}$ \\
\hline & & & $\begin{array}{l}\text { B8 } \\
\text { B9 }\end{array}$ & $\begin{array}{l}388 \\
385 \\
330\end{array}$ \\
\hline & & & $\begin{array}{l}\text { B10 } \\
\text { B11 } \\
\text { B12 } \\
\text { C1 } \\
\text { C2 } \\
\text { C3 }\end{array}$ & $\begin{array}{r}0 \\
375 \\
285 \\
385 \\
385 \\
373 \\
385\end{array}$ \\
\hline & & & $\begin{array}{l}\text { C4 } \\
\text { C5 } \\
\text { D1 } \\
\text { E1 } \\
\text { F1 } \\
\text { G1 }\end{array}$ & $\begin{array}{r}388 \\
0 \\
158 \\
0 \\
185 \\
0\end{array}$ \\
\hline
\end{tabular}

Thus, acquisition of resistance genes by transposition from other plasmids carried by other bacteria in the host is very common. ${ }^{13,20}$ We have shown previously that the major RTs found among Typhimurium strains are also common among strains of other Salmonella serotypes isolated during a 3-year period in Iran. ${ }^{4}$ In contrast, phage typing has been considered as the method of choice for differentiating Typhimurium strains. ${ }^{13,21}$ Again, although the method is essential for primary subdivision of this serotype, it has proved insufficiently discriminatory in areas where a limited number of phage types predominate..$^{22}$ Furthermore, it has been shown that carriage of $\mathrm{R}$ - and other factors by Typhimurium strains may restrict multiplication of infecting phages, reduce sensitivity, and result in interconversion of phage types of certain strains. ${ }^{23,24}$ 
We have shown already that the frequency of resistance factors for the antibiotics used in this study varied between 20 and $83 \%$ among Typhimurium strains from Iran. ${ }^{4}$ Based on these observation, we postulated that variations observed in PTs or RTs of strains of the same BPT might reflect antibiotic pressure in Iran. ${ }^{4,25}$

Barker et $a l .{ }^{26}$ testing 2010 Typhimurium strains isolated from different sources over a 3-year period in Scotland, found that four major phage-type/biotype groups (epidemic strains) accounted for $>50 \%$ of their cultures. Our findings, based on combinations of BPT, PT and RT, also demonstrate that most of the Typhimurium strains isolated during 1 year in Iran belonged to a few major BPT/PT/RTs and support the claim of Anderson ${ }^{27}$ that, in any country where conditions are favourable for the establishment of salmonellae in man and animals, relatively few clones are responsible for the majority of infections.

The main difference found in the biochemical reactions of the dominant BPTs B1 and B4 among our isolates was the rate of trehalose fermentation. Duguid et al. ${ }^{5}$ showed that Typhimurium strains isolated from different sources during the same outbreak had a stable biotype under natural conditions. However, they found that, after several years of storage, a few strains showed different patterns of trehalose fermentation and postulated that such differences were probably due to the selection of mutant strains during subculture. The strains tested in our study had also been stored for a long period before testing biochemical phenotypes. We previously evaluated, with the PhP-system, the stability of the biochemical phenotypes of enteropathogenic strains of Escherichia coli upon subculture and storage and observed that certain biochemical reactions of the bacteria changed slightly after subculture, storage or both. ${ }^{28}$ Elsewhere, ${ }^{17}$ we

\section{References}

1 Mitchell E, O'Mahony M, Lynch D et al. Large outbreak of food poisoning caused by Salmonella typhimurium definitive type 49 in mayonnaise. $B M J 1989 ; 298$ : 99-101.

2. Fule RP, Ninawe RW, Saoji AM. Outbreak of gastroenteritis due to Salmonella typhimurium in Solapur. Indian Pediatr 1988; 25 : 57-60.

3. Turnbull PCB. Food poisoning with special reference to Salmonella-its epidemiology, pathogenesis and control. Clin Gastroenterol 1979; 8: 663-714.

4. Farhoudi-Moghaddam AA, Katouli M, Jafari A, Behavar MA, Parsi M, Malekzadah F. Antimicrobial drug resistance transfer factor among clinical isolates of salmonellae in Iran. Scan J Infect Dis 1990; 22: 197-203.

5. Duguid JP, Anderson ES, Alfredsson GA, Barker R, Old DC. A new biotyping scheme for Salmonella typhimurium and its phylogenetic significance. J Med Microbiol 1975; 8: 149-166.

6. Anderson ES, Ward LR, De Saxe MJ, De Sa JDH. Bacteriophage-typing designations of Salmonella typhimurium. J Hyg 1977; 78: 297-300.

7. Guinee PAM, Jansen WH, van Schuylenberg A, van Leeuwen JW. Bacteriophage typing of Salmonella typhimurium by use of a mechanized technique. Appl Microbiol 1973; 26: 474-477.

8. Anderson ES. Drug resistance in Salmonella typhimurium and its implications. $B M J 1968 ; 3$ : 333-339. have reported similar changes in some biochemical reactions (including trehalose) of Typhimurium strains after subculture.

Biotyping of Typhimurium strains has delineated a special group of non-fimbriated (fim-), inositol and rhamnose non-fermenting strains termed "FIRN". ${ }^{29}$ In an investigation of 2092 Typhimurium strains, Anderson et al..$^{30}$ found that $13 \%$ of strains belonged to the FIRN group, all of which were also D-xylosenegative. Based on genetical evidence, ${ }^{31,33}$ it has been suggested that FIRN strains have descended from a single clone (ino-, rha-, fim + ) which has undergone successive mutations to fimbriation-negative and rhamnose fermentation-negative states. We did not investigate the presence of fimbriae among our ino-, rha - strains, but they fermented xylose slowly and belonged to phenotypes quite unlike others found in this study. Again, they differed from each other mainly in their galactonic-lactone reactions, suggesting that the ability to ferment galactonic-lactone (at least within the population tested in our study) may be an important biochemical character in tracing the origins of Typhimurium strains.

In conclusion, we found that strains of two major and probably related clones of Typhimurium were responsible for the majority of Typhimurium infections in Iran. Although each method detected these and other less common types in the population tested, biochemical fingerprinting by the PhP-system gave additional discrimination with regard to variety (number of phenotypes) and its ability to demonstrate possible clonal relationships among the strains.

We thank Ms Birgitta Karlsson and Ms Gunnel Sigstam for skilful technical assistance. This study was supported by The Swedish Board for Agricultural and Forestry Research (grant numbers 0564/89 L 139 and 0777/89 D 326), The Swedish Farmers' Foundation for Agricultural Research (grant 912912) and The Karolinska Institute Fund.

9. Brunner, F, Margadant A, Peduzzi R, Piffaretti J-C. The plasmid pattern as an epidemiologic tool for Salmonella typhimurium epidemics: comparison with the lysotype. $J$ Infect Dis 1983; 148: 7-11.

10. Taylor DN, Wachsmuth IK, Shangkuan Y-H et al. Salmonellosis associated with marijuana. A multistate outbreak traced by plasmid fingerprinting. $N$ Engl J Med $1982 ; 306$ : 1249-1253.

11. Kapperud G, Lassen J, Dommarsnes K et al. Comparison of epidemiological marker methods for identification of Salmonella typhimurium isolates from an outbreak caused by contaminated chocolate. J Clin Microbiol 1989; 27: 2019-2024

12. Platt DJ, Brown DJ, Old DC, Barker RM, Munro DS, Taylor J. Old and new techniques together resolve a problem of infection by Salmonella typhimurium. Epidemiol Infect 1987; 99 : 137-142.

13. Threlfall EJ, Frost JA. The identification, typing and fingerprinting of Salmonella: laboratory aspects and epidemiological applications. J Appl Bacteriol 1990; 68: 5-16.

14. Barker RM, Old DC. The usefulness of biotyping in studying the epidemiology and phylogeny of salmonellae. $J \mathrm{Med}$ Microbiol 1989; 29: 81-88.

15. Kühn I. Biochemical fingerprinting of Escherichia coli: a simple method for epidemiological investigations. $J$ Microbiol Methods 1985; 3: 159-170.

16. Kuhn I, Burman LG, Eriksson L, Möllby R. Subtyping of 
Klebsiella by biochemical fingerprinting: a simple system for epidemiological investigations. J Microbiol Methods $1990 ; 11: 177-185$.

17. Katouli M, Kühn I, Wollin R, Möllby R. Evolution of the PhP system for biochemical-fingerprint typing of strains of Salmonella of serotype Typhimurium. J Med Microbiol $1992 ; 37: 245-251$.

18. Lilleengen K. Typing of Salmonella typhimurium by means of bacteriophage. Acta Pathol Microbiol Scand Suppl LXXVII 1948.

19. Sneath PHA, Sokal RR, Numerical taxonomy. The principles and practice of numerical classification. San Francisco, WH Freeman. 1973.

20. Eisenstein BI. New molecular techniques for microbial epidemiology and the diagnosis of infectious diseases. $J$ Infect Dis 1990 ; 161 : 595-602.

21. Barker RM, Old DC, Munro DS, Taylor J. Prevalent phage types of Salmonella typhimurium in Scotland. Communicable Diseases Scotland Weekly Report 1987; 20: 5-7.

22. Barker RM, Old DC. Biotypes of strains of Salmonella typhimurium of phage types 49, 204 and 193. J Med Microbiol 1980; 13: 369-371.

23. Anderson ES. Influence of the $\Delta$ transfer factor on the phage sensitivity of salmonellae. Nature 1966; 212: 795-799.

24. Anderson ES, Threlfall EJ, Carr JM, Savoy LG. Bacteriophage restriction in Salmonella typhimurium by $\mathbf{R}$ factors and transfer factors. J Hyg 1973; 71: 619-631.

25. Katouli M, Pachenary A, Jafari A et al. The role of Shigella spp. in childhood diarrhoea in Iran and their antibiotic resistance. Scand J Infect Dis $1989 ; 21$ : 415-419.

26. Barker RM, Old DC, Sharp JCM. Phage type/biotype groups of Salmonella typhimurium in Scotland 1974-6: variation during spread of epidemic clones. J Hyg 1980; 84: 115-125.

27. Anderson ES. The modern ecological study of Salmonella typhimurium infection. In: Perez-Miravete A, Peleaz (eds) Xth International Congress for Microbiology, Mexico City 1970 (Proceedings). Recent advances in microbiology 1971: 381.

28. Katouli, M, Kühn I, Möllby R. Evaluation of the stability of biochemical phenotypes of Escherichia coli upon subculturing and storage. $J$ Gen Microbiol 1990; 136: 1681-1688.

29. Morgenroth A, Duguid JP. Demonstration of different mutational sites controlling rhamnose fermentation in FIRN and non-FIRN rha- strains of Salmonella typhimurium: an essay in bacterial archaeology. Gen Res 1968;11: 15I-169.

30. Anderson ES, Ward, de Saxe MJ, Old DC, Barker R, Duguid JP. Correlation of phage type, biotype and source in strains of Salmonella typhimurium. J Hyg 1978; 81: 203-217.

31. Old DC. Temperature-dependent utilization of meso-inositol: a useful biotyping marker in the genealogy of Salmonella typhimurium. J Bacteriol 1972; 112: 779-783.

32. Old DC, Duguid JP. Transduction of fimbriation demonstrating common ancestry in FIRN strains of Salmonella typhimurium. J Gen Microbiol 1979; 112: 251-259.

33. Old DC. Phylogeny of strains of Salmonella typhimurium. Microbiol Sciences 1984; 1 : 69-72 